\title{
Patient Safety in Drug Therapy and the Influence of the Prescription in Dose Errors ${ }^{1}$
}

\author{
Fernanda Raphael Escobar Gimenes² \\ Maria Ludermiller Sabóia Mota ${ }^{3}$ \\ Thalyta Cardoso Alux Teixeira ${ }^{4}$ \\ Ana Elisa Bauer de Camargo Silva ${ }^{5}$ \\ Simone Perufo Opitz ${ }^{6}$ \\ Silvia Helena De Bortoli Cassiani
}

The aims of this study were to analyze the redaction of the prescription in dose errors that occurred in general medical units of five Brazilian hospitals and to identify the pharmacological classes involved in these errors. This was a descriptive study that used secondary data obtained from a multicenter study conducted in 2005. The population consisted of 1,425 medication errors and the sample of 215 dose errors. Of these, $44.2 \%$ occurred in hospital $E$. The presence of acronyms and/or abbreviations was verified in $96.3 \%$ of prescriptions; absence of the patient registration in $54.4 \%$; absence of posology in $18.1 \%$; and omission of date of $0.9 \%$. With respect to medication type, $16.8 \%$ were bronchodilators; $16.3 \%$ were analgesics; $12.1 \%$, antihypertensives; and $8.4 \%$ were antibiotics. The absence of posology in the prescriptions may facilitate the administration of the wrong dose, resulting in inefficiency of the treatment, compromising the quality of care provided to hospitalized patients.

Descriptors: Medication Errors; Drug Prescriptions; Dosage; Nursing; Therapeutics; Clinical Pharmacology; Hospital Medication System.

\footnotetext{
${ }^{1}$ Article extrated from Master's Dissertation "A segurança de pacientes na terapêutica medicamentosa: análise da redação da prescrição médica nos erros de administração de medicamentos em unidades de clínica médica", presented to Escola de Enfermagem de Ribeirão Preto, Universidade de São Paulo, WHO Collaborating Centre for Nursing Research Development, SP, Brazil.

2 M.Sc. in Nursing, Professor, UNICASTELO, SP, Brazil. E-mail: fer_gimenes@yahoo.com.br.

3 Ph.D. in Pharmacology, Professor, Universidade de Fortaleza, CE, Brazil. E-mail: mila269@terra.com.br.

${ }^{4}$ RN, M.Sc. in Nursing, Hospital Vera Cruz, Campinas, SP, Brazil. E-mail: thalytacat@yahoo.com.br.

${ }^{5}$ Ph.D. in Nursing, Professor, Universidade Federal de Goiás, GO, Brazil. E-mail: anaelisa@terra.com.br.

${ }^{6}$ Ph.D. in Nursing, Professor, Universidade Federal do Acre, AC, Brazil. E-mail: simoneop@bol.com.br.

7 Ph.D. in Nursing, Full Professor, Escola de Enfermagem de Ribeirão Preto, Universidade de São Paulo, WHO Collaborating Centre for Nursing Research Development, SP, Brazil. E-mail: shbcassi@eerp.usp.br.
}

Corresponding Author:

Silvia Helena De Bortoli Cassiani

Universidade de São Paulo. Escola de Enfermagem de Ribeirão Preto.

Departamento de Enfermagem Geral e Especializada.

Av. Bandeirantes, 3.900

Bairro Monte Alegre

CEP: 14.040-902 Ribeirão Preto, SP, Brasil

E-mail: shbcassi@eerp.usp.br 


\title{
Segurança do paciente na terapêutica medicamentosa e a influência da prescrição médica nos erros de dose
}

Os objetivos foram analisar a redação da prescrição médica nos erros de doses, ocorridos em unidades de clínica médica de cinco hospitais brasileiros, e identificar as classes farmacológicas envolvidas nesses erros. Este é estudo descritivo que utilizou dados secundários, obtidos de pesquisa multicêntrica, realizada em 2005. A população foi composta por 1425 erros de medicação e a amostra por 215 erros de doses. Desses, $44,2 \%$ ocorreram no hospital E. Verificou-se presença de siglas e/ou abreviaturas em $96,3 \%$ das prescrições, ausência do registro do paciente em $54,4 \%$, falta de posologia em $18,1 \%$ e omissão da data em $0,9 \%$. Com relação ao tipo de medicamento, $16,8 \%$ eram broncodilatadores, $16,3 \%$ eram analgésicos, $12,1 \%$, anti-hipertensivos e 8,4\% eram antimicrobianos. A ausência da posologia nas prescrições pode favorecer a administração de doses erradas, resultando em ineficiência do tratamento, comprometendo a qualidade da assistência prestada aos pacientes hospitalizados.

Descritores: Erros de Medicação; Prescrição de Medicamentos; Dosagem; Enfermagem; Terapêutica; Farmacologia Clínica; Sistema de Medicação no Hospital.

\section{Seguridad del paciente en la terapéutica medicamentosa y la influencia de la prescripción médica en los errores de dosis}

\begin{abstract}
Los objetivos fueron analizar la redacción de la prescripción médica en los errores de dosis ocurridos en unidades de clínica médica de cinco hospitales brasileños e identificar las clases farmacológicas envueltas en esos errores. Se trata de estudio descriptivo que utilizó datos secundarios obtenidos de en una investigación multicéntrica realizada en 2005. La población fue compuesta de 1.425 errores de medicación y la muestra por 215 errores de dosis. De estos, 44,2\% ocurrieron en el hospital E. Se verificó: presencia de siglas y/o abreviaturas en $96,3 \%$ de las prescripciones; ausencia del registro del paciente en 54,4\%; falta de posología en $18,1 \%$, y omisión de la fecha en $0,9 \%$. Con relación al tipo de medicamento, $16,8 \%$ eran broncodilatadores; $16,3 \%$ eran analgésicos; $12,1 \%$, antihipertensivos y $8,4 \%$ eran antimicrobianos. La ausencia de la posología en las prescripciones puede favorecer la administración de dosis equivocadas, resultando en ineficiencia del tratamiento, comprometiendo así, la calidad de la asistencia prestada a los pacientes hospitalizados.
\end{abstract}

Descriptores: Errores de Medicación; Prescripciones de Medicamentos; Dosificación; Enfermería; Terapéutica; Farmacología Clínica; Sistemas de Medicación en Hospital.

\section{Introduction}

Medication errors are a serious problem in current health services being considered one of the main adverse events suffered by hospitalized patients. Among all medication errors occurring in hospitals, that of dosage seems to be one of the most frequent ${ }^{(1)}$.

In this context, the actions of the nurse in therapeutic implementation can modify the pharmacodynamic and pharmacokinetic processes of the drugs, since medication administration is the responsibility of this professional and in this context, checking the dose becomes extremely relevant, as does the monitoring of administration schedules and adverse reactions to medications. This responsibility for the dose is justified by the concept of systemic availability, commonly known as bioavailability, which is a term used to describe the proportion of administered drug that reaches the systemic circulation and is thus available for distribution to the site of action(2). In this sense, it is important to 
note that the dose needs to be rigorously complied with so as to achieve the optimal systemic availability profiles for each drug prescribed and administered.

The occurrence of the nursing team leaving some remaining medication in the infusion set can be cited as an example. In this case, the loss is proportionally greater the more concentrated the solution is and this can be considered a dose error(3).

Regarding the role of prescriptions, it is known that they have an important role in preventing adverse events related to incorrect dose. This is because they can contribute to the occurrence of these errors when ambiguous, illegible or incomplete, due to a lack of standardization of the nomenclature of the prescribed medication, as well as when abbreviations are used or there is the presence of erasures ${ }^{(4-5)}$.

Drug prescriptions must be presented clearly and legibly(6) and, moreover, the Law 5.991/73(7) establishes requirements that must be adopted during their redaction, including the posology specification, information which is essential for medication safety.

In recent years, national studies have been carried out in order to identify errors in medication processes, especially in the steps of dispensing ${ }^{(8)}$, preparation ${ }^{(9)}$ and administration of the dose, however, little is known about the role the prescription plays in dose error rates and their consequences for nursing actions with regard to safety in drug therapy.

The aims of this study were to analyze the redaction of the prescription in dose errors that occurred in general medical units of five Brazilian hospitals and to identify the major pharmacological classes involved in these errors.

\section{Methods}

This was a descriptive study that used secondary data obtained from a multicenter study conducted in 2005 in five Brazilian University Hospitals, referred to as $A, B, C, D$ and $E$, all belonging to the Network of Sentinel Hospitals of ANVISA. The previous study was approved by the hospitals investigated and by the Research Ethics Committee, protocol n 12216/2004. For the realization of this research a request was submitted to the REC regarding the waiver of the Free Prior Informed Consent (FPIC) form due to this being a secondary analysis of data, and this was approved, protocol $n^{\circ}$ 0684/2006.

The study population consisted of 1,425 medication errors and, the sample of 215 dose errors. To this end, the information stored in the EpiData version 3.1 databases of the five hospitals surveyed was used, contained in the data collection instrument from a multicenter study that addressed the medication prescription, as well as data on the preparation and administration of doses. For both, direct non-participatory observation of the stages in the preparation and administration was carried out, comparing the information obtained with the original prescriptions. From the comparison, the error was identified, classified and described.

For the analysis of the presence or absence of items in the redaction of the information contained in the prescriptions and that could contribute to dose errors, the following variables were considered: Absence of Patient Data (Bed \& Registration); Absence of Date; Absence of Medication Data (Dose) Presence of Acronyms and/or Abbreviations; Presence of Alteration and/or Suspension of Medication and/or Presence of Erasures.

The data were crossed by using the program SPSS 11.5 (SPSS Inc., Chicago, II., USA) and the results obtained from this analysis were tabulated, constructed as graphs and expressed as distribution of absolute frequencies and percentages.

\section{Results}

Of the 215 total dose errors, 25 occurred in hospital A (11.6\%), 20 (9.3\%) in hospital B, 30 (14.0\%) in C, $45(20.9 \%)$ in D, and 95 (44.2\%) occurred in hospita $\mathrm{E}$. The most common problem found in the prescriptions of doses was regarding the presence of acronyms and/ or abbreviations that were present in 207 (96.3\%) dose errors (e.g. Cedilanide $1 / 2$ amp IV; Haldol 1/4 tablet PO; dipyrone ampoule IV ADD; KCL syrup 1 med PO) (Table 1).

There was also a absence of patient registration number in 117 (54.4\%) prescriptions; the posology of the medication was absent in 39 (18.1\%) (e.g. ranitidine tablet $\mathrm{VO}$ ) and a absence of bed number in two (0 9\%). Also, the date was omitted in two (0.9\%) prescriptions. However, the name of the patient was present in all situations in which the dose administered was different to that prescribed.

Table 1 also shows the distribution of dose errors, which could be related to the presence or absence of items in the prescription, according to the hospital investigated. 
Table 1 - Distribution of frequency of dose errors, following the presence or absence of items in the prescription of general medical units of five Brazilian hospitals, 2006

\begin{tabular}{|c|c|c|c|c|c|c|c|c|c|c|c|c|}
\hline \multirow{3}{*}{ Items of the prescription* } & \multicolumn{12}{|c|}{ Hospital } \\
\hline & \multicolumn{2}{|c|}{$\begin{array}{c}A \\
(n=25)\end{array}$} & \multicolumn{2}{|c|}{$\begin{array}{c}B \\
(n=20)\end{array}$} & \multicolumn{2}{|c|}{$\begin{array}{c}C \\
(n=30)\end{array}$} & \multicolumn{2}{|c|}{$\begin{array}{c}D \\
(n=45)\end{array}$} & \multicolumn{2}{|c|}{$\begin{array}{c}E \\
(n=95)\end{array}$} & \multicolumn{2}{|c|}{$\begin{array}{c}\text { Total } \\
(\mathrm{n}=215)\end{array}$} \\
\hline & $\mathbf{n}$ & $\%$ & $\mathbf{n}$ & $\%$ & $\mathbf{n}$ & $\%$ & $\mathbf{n}$ & $\%$ & $\mathbf{n}$ & $\%$ & $\mathbf{n}$ & $\%$ \\
\hline Absence of patient data (bed) & 0 & 0.0 & 0 & 0.0 & 0 & 0.0 & 0 & 0.0 & 2 & 2.1 & 2 & 0.9 \\
\hline Absence of patient data (registration) & 0 & 0.0 & 0 & 0.0 & 2 & 6.7 & 27 & 60.0 & 88 & 92.6 & 117 & 54.4 \\
\hline Absence of date & 0 & 0.0 & 0 & 0.0 & 0 & 0.0 & 1 & 2.2 & 1 & 1.1 & 2 & 0.9 \\
\hline Absence of medication data (dose) & 3 & 12.0 & 0 & 0.0 & 15 & 50.0 & 12 & 26.7 & 9 & 9.5 & 39 & 18.1 \\
\hline Presence of acronyms and/or abbreviations & 22 & 88.0 & 20 & 100.0 & 28 & 93.3 & 44 & 97.8 & 93 & 97.9 & 207 & 96.3 \\
\hline Presence of changes and/or suspension of the medication & 2 & 8.0 & 1 & 5.0 & 3 & 10.0 & 0 & 0.0 & 2 & 2.1 & 8 & 3.7 \\
\hline Presence of erasures & 1 & 4.0 & 0 & 0.0 & 3 & 10.0 & 2 & 4.4 & 7 & 7.4 & 13 & 6.4 \\
\hline
\end{tabular}

* Each prescription may present more than one inadequacy.

The use of acronyms and abbreviations was the most common problem identified in the prescriptions of the five study hospitals. Of the 25 dose errors occurring in hospital A, $22(88.0 \%)$ presented acronyms and/or abbreviations. In hospital B, all $20(100.0 \%)$ prescribed doses presented them. In C, 28 (93.3\%) of the 30 dose errors contained them. In hospital D, 44 (97.8\%) of the 45 dose errors contained them, and in hospital E, 93 (97.9\%) of the 95 dose errors also contained these types of data.

Even hospital A, where the prescription is computerized, revealed some problems related to the omission of information in the prescriptions, such as absence of dosage (in milligrams) in three prescriptions $(12.0 \%)$, the presence of alterations in two (8.0\%) and deletions in one $(4.0 \%)$ of the total of 25 prescriptions involved in dose errors.

Of the 20 drugs administered with different doses to those prescribed in hospital $\mathrm{B}$, there were alterations in the information in one prescription (5.0\%). Hospital
C lacked the dosage in 15 prescriptions (50.0\%); the patient registration in two $(6.7 \%)$; and showed the presence of erasures and alterations in the information in three prescriptions (10.0\%). In hospital D, the patient registration number was omitted in 27 (60.0\%) of the total of 45 prescriptions; the dosage in 12 (26.7\%); presented deletions in two (4.4\%) and absence of the prescription date in one case $(2.2 \%)$.

Table 1 also shows that in hospital E, where the prescription system is mixed, there was an absence of patient registration number in 88 (92.6\%) of the 95 prescriptions, the dose was omitted in nine $(9.5 \%)$; deletions were present in seven (7.4\%), alterations and/ or discontinuation of the drugs, as well as the absence of the bed number present in two $(2.1 \%)$ and the date of redaction missing in one prescription.

Figure 1, gives examples of medications involved in errors, where the prescription was found to be incomplete and/or to contained acronyms and/or abbreviations.

\begin{tabular}{|l|l|l|}
\hline \multicolumn{1}{|c|}{$\begin{array}{c}\text { Dose of medication administered different } \\
\text { to that prescribed }\end{array}$} & \multicolumn{1}{|c|}{ Prescription } & \multicolumn{1}{c|}{ Description } \\
\hline Situation 1: Administered three ampoules of Bactrim IV. & Bactrim ampoule IV. & Absence of dosage. \\
\hline $\begin{array}{l}\text { Situation 2: Administered } 2 \mathrm{ml} \text { dipyrone IV, diluted in } 18 \\
\mathrm{ml} \text { of AD. }\end{array}$ & Dipyrone 40 drops PO. & $\begin{array}{l}\text { The prescription of the drug was erased Dipyrone 2:18 } \\
\text { AD IV and replaced with 40 drops PO. }\end{array}$ \\
\hline $\begin{array}{l}\text { Situation 3: Administered Buscopan } 1 \mathrm{ml} \text { diluted in } 9 \mathrm{ml} \\
\text { of AD, IV. }\end{array}$ & Buscopan 2:18 AD IV. & $\begin{array}{l}\text { Absence of dose (in mg), abbreviated } 2 \mathrm{ml} \text { of the drug to } \\
2: 18 \mathrm{ml} \text { of diluent, absence of the dosage form. }\end{array}$ \\
\hline
\end{tabular}

Figure 1 - Examples of situations where discrepancies were verified between the prescribed dose and that administered

Regarding the type of drug involved in the errors of dose, $16.8 \%$ were bronchodilators such as fenoterol hydrobromide (94.4\%) and terbutaline $(2.8 \%)$ and $16.3 \%$ were analgesics such as dipyrone (37.1\%) and tramadol hydrochloride (25.7\%). Also, $12.1 \%$ were anti-hypertensive drugs such as captopril (43.5\%) and carvedilol (26.1\%) and $8.4 \%$, antibiotics, of these, $27.8 \%$ were related to the administration of clindamycin phosphate and $11.1 \%$ to ciprofloxacin (Table 2 ). 
Table 2 - Distribution of frequency of dose errors which occurred in general medical units of five Brazilian hospitals by drug type, 2006

\begin{tabular}{lcc}
\hline \multirow{2}{*}{ Classes of Medication } & \multicolumn{2}{c}{ Frequency } \\
\cline { 2 - 3 } & $\mathbf{n}$ & $\%$ \\
\hline Bronchodilators & 36 & 16.7 \\
Analgesics & 35 & 16.3 \\
Antihypertensives & 26 & 12.1 \\
Vitamins e minerals & 20 & 9.3 \\
Antibiotics & 18 & 8.4 \\
Anti-inflammatories & 14 & 6.5 \\
Diuretics & 10 & 4.6 \\
Hypoglycemics & 8 & 3.7 \\
Antiulcerants & 7 & 3.3 \\
Spasmolytics & 5 & 2.3 \\
Anticoagulants & 4 & 1.9 \\
Antineutropenics & 3 & 1.4 \\
Others & 29 & 13.5 \\
Total & 215 & 100.0 \\
\hline
\end{tabular}

\section{Discussion}

Studies have indicated that dose errors are one of the most frequent problems related to medication administration, interfering with quality of care provided to hospitalized patients ${ }^{(10)}$. When the prescriber does not specify the required dosage in milligrams, opting for the use of abbreviations or acronyms, there is a risk of the patient receiving a dose of medication different to the prescription, as drugs such as dipyrone, for example, have several dosage forms available on the market $(1 \mathrm{ml}$ ampoules containing $500 \mathrm{mg}, 2 \mathrm{ml}$ ampoules containing $500 \mathrm{mg} / \mathrm{ml}, 5 \mathrm{ml}$ ampoules containing $500 \mathrm{mg} / \mathrm{ml}$ ). Thus, in the prescription of the type dipyrone ampoule IV $A D D$, the following question could emerge: What dose should be administered to the patient? $500 \mathrm{mg}$ ? 1,000 $\mathrm{mg}$ ? or 2,500 mg?

Adequate identification of the patient is also necessary for safe medication administration, as clients with similar names, in the same hospital ward and receiving the same medication but in different doses, can be easily confused and receive a dose inappropriate for their treatment.

A study performed in an outpatient clinic of a primary care unit in Aracajú-SE identified an absence of posology in $40 \%$ of the prescriptions dispensed ${ }^{(11)}$. In research conducted in a midsize public general hospital in Fortaleza an absence of posology was detected in $30.1 \%$ of the prescriptions in the medical clinic(12). It is known that in the absence of posology in the prescriptions can lead to the administration of lower or higher doses than desired, resulting in ineffectiveness of treatment or even the death of the patient from intoxication. The professionals of the nursing team must therefore require from the health services actions in order to prevent prescribers from omitting this information to promote safety in dose administrations.

With respect to erasures, their presence was identified in $17.5 \%$ of the prescriptions, as well as the use of acronyms and abbreviations in $28.0 \%$ in research conducted in three inpatient units of a large university hospital in the state of São Paulo(13). The presence of acronyms and abbreviations can also lead to dosage errors. For example, using the abbreviation " $U$ " for "unit" is very problematic, because the prescribed dose of $100 \mathrm{U}$ of heparin is easily read as 1000 units when there is no space between the numerical dose and the abbreviation " $U$ "(3). The risk of errors is increased to the extent that nurses and other health professionals are not able to correctly read the prescriptions, resulting in confusion during the dispensing, distribution, preparation and administration of the medication. Thus, the National Coordinating Council for Medication Error and Prevention (NCC MERP) $^{(14)}$ recommended the implementation of a computerized prescription system, not allowing the use of acronyms and abbreviations, even those standardized by the institution, so that misinterpretation of information does not occur and also recommended that "gaps" are avoided in prescriptions of the type dipyrone IV $Y / N$ ( $\mathrm{Y} / \mathrm{N}$ "if necessary") or dipyrone IV ADD (ADD for "at the doctors discretion") for greater safety in the medication administration.

The prescription of medication is seen as the beginning of a series of events, within the process of medication, which will result in the safe, or unsafe, administration of a dose to the patient. Therefore, a greater awareness is necessary from those who prescribe, in order to write prescriptions clearly, objectively and completely, minimizing the doubts of the multidisciplinary team and providing favorable conditions for patient safety in drug therapy.

Although the nurse is not directly responsible for redacting the prescription, it is important that these professionals have knowledge about the system as a whole, i.e. from the moment that the drug is prescribed until its administration, in order to identify the flaws inherent in the process and to prevent errors from reaching the patient. It is known that the professional nurse supervises their personnel in the administration process, but lack a more defined operation within the system as a whole ${ }^{(15)}$. 
Furthermore, the results of this study, described in the graph, corroborate findings in the literature regarding the presence of groups of drugs most prescribed in the quotidian of various health institutions. The $B_{2}$-agonists (bronchodilatory action), for example, are administered by inhalation and often prescribed in conjunction with corticosteroids (anti-inflammatory and anti-allergic), which is the preferred treatment for acute episodes of bronchoconstriction ${ }^{(16)}$. These constitute a common point in most therapeutic protocols and consensuses, directed to the occurrence of the problem.

The antibiotics are also one of the groups of medication most prescribed in hospitals and that cause great concern regarding the adequacy of their use(2). The correct administration of the dose, concentration and infusion time of a medication, in general, largely depends on the nursing team. Higher concentrations (dose errors) and too-rapid infusion can cause local reactions, such as inflammation, infection and the need for treatment and even cutaneous and systemic reactions, generating errors that lead to unnecessary changes in the prescribed treatment ${ }^{(17)}$.

The therapeutic and toxic effects, in the short term, of the drugs prescribed for the correction of any pathological condition occur as a result of pharmacological actions which, in turn, are dose dependent. However, the translation of pharmacological, molecular and cellular effects into therapeutic or toxic effects is not a simple process, since it involves several stages of transformation at different pharmacological and physiological levels.

The administration of doses lower than the patient needs can lead to desensitization of receptors and lack of therapeutic effects. Furthermore, the administration of doses higher than the patient needs can lead to adverse events related to important organ systems such as the heart (tachycardia) and central nervous system (psychomotor disorientation and peripheral tremors). Either way there is clinical injury to the patient, who does not adequately benefit from the medication. Therefore, ignorance, on the part of the nursing team, of basic pharmacological aspects can induce errors such as the non-observance of the administration of the exact dose needed and the correct schedule for each patient and may cause various clinical consequences ranging from lack of response to intolerable toxicity. One example is a study on the preparation and administration of vancomycin by the nursing team, where $57 \%$ of dose administrations were identified as being incomplete, due to the amount of solution that remained in the infusion equipment after administration(3).

The American Society of Health System Pharmacists ${ }^{(17)}$ in its standardization, still followed in 2008, referring to the distribution and control of drugs underscores the attention necessary to the risks of administration of incompatible molecules in relation to types of administration systems. The responsibility for administering the medication, for monitoring the patient until the end of infusion, and the specific training to administer medication are some of the aspects mentioned. Standards should be developed by the institutions themselves and redacted in detail.

\section{Conclusion and final considerations}

The results presented in this study reveal that many patients do not receive doses appropriate for their treatment, which compromises the quality of care provided, and extends the length of hospitalization. Furthermore, inadequate doses may cause undesirable effects and even the death of the individual.

It was noticed that many prescriptions do not meet the current standards of the country with regard to the completeness and clarity of information. This was evident from the presence of abbreviations in $96.3 \%$ of all prescriptions dispensed in the hospitals investigated. The presence of these data can affect the understanding of the information by the nursing team who are directly responsible for preparing and administering the doses. Moreover, the absence of posology in the medical prescription can promote the administration of lower or higher doses in relation to that required for the treatment, resulting in not reaching the pharmacotherapeutic goals established.

With regard to the pharmacological classes most involved in this type of error, bronchodilators composed the majority, followed by analgesics, anti-hypertensives, and antibiotics.

It is possible to understand from this study that nursing has a broad responsibility for the process of therapeutic monitoring of the patient and that these professionals need more specific academic training in the field of pharmacology, with a view to the comprehension that medication is an important weapon against disease, however, this intent can only be achieved with the correct use of each molecule prescribed. 


\section{References}

1. Joanna Briggs Institute. Strategies to reduce medication errors with reference to older adult. Best Practice. 2009;9(4):1-6.

2. Labarca JL. Nuevos conceptos en farmacodinamia, debemos repensar cómo administramos antimicrobianos?. Rev Chilena Infectol. 2002;19(Suppl 1):33-7.

3. Hoefel HHK, Zini L, Lunardi T, Santos JB, Mahmud S, Magalhaes $A M$, et al. Vancomycin administration in an universitary hospital at general surgical units inpatients. Online Braz $]$ Nurs [serial on the Internet]. 2004 Apr [acesso 15 nov 2008]; 3(1). Disponível em: http://www.uff.br/nepae/objn301hoefeletal.htm

4. Cohen MR. Letter and number characters that run together may lead to serius errors. Int J Pharm. 1999;13(3):108-9.

5. Cassiani SHB, Freire CC, Gimenes FRE. A prescrição médica eletrônica em um hospital universitário: falhas de redação e opiniões de usuários. Rev Esc Enferm USP. 2003;37(4):51-60.

6. Conselho Federal de Medicina. Código de Ética Médica. Resolução n 1246, 8 de janeiro de 1988. Diário Oficial da República Federativa do Brasil, 26 de jan. 1988.

7. Lei n 5.991, de 17 de dezembro de 1973. Dispõe sobre o controle sanitário do comércio de drogas, medicamentos, insumos farmacêuticos e correlatos, e dá outras providências. Diário Oficial da União, Brasília, DF, 19 de dezembro de 1973. $152^{\circ}$ da Independência e $85^{\circ}$ da República; 1973.

8. Costa LA, Valli C, Alvarenga AP. Medication dispensing errors at a public pediatric hospital. Rev. Latino-Am. Enfermagem. 2008;16(5):812-7.

9. Oliveira RC, Casssiani SHB. Characterization of the structure for medication preparation in teaching-hospitals: factors that interfere with the quality of care. Rev. Latino-Am. Enfermagem. 2007; 15(2):224-9.
10. Rothschild JM, Keohane CA, Cook EF, Orav EJ, Burdick E, Thompson S, et al. A controlled trial of smart pumps to improve medication safety in critically ill patients. Crit Care Med. 2005;33(3):533-40.

11. Lyra-Junior DP, Prado MC, Abriata JP, Pela IR. Recetas médicas como causantes de riesgo de problemas relacionados con medicamentos. Seguim Farmacoter. 2004;2(2):86-96.

12. Aguiar G, Silva-Junior LA, Ferreira MAM. Ilegibilidade e ausência de informações nas prescrições médicas: fatores de risco relacionados a erros de medicação. RBPS. 2005;19(2):84-91.

13. Gimenes FRE, Miasso AI, Lyra-Junior DP, Grou CR. Electronic prescription as contributory factor for hospitalized patients' safety. Pharmacy Practice. 2006;4(1):13-7.

14. National Coordinating Council for Medication Error Reporting and Prevention [homepage on the Internet]. Rockville: The Association; c1998-2009 [updated 2005 Sep 23; cited 2009 Jan 10]. What is medication error?; [about 1 screen] Available from: http://www.nccmerp.org/council/council1996-09-04.html 15. Cassiani SHB, Miasso AI, Silva AEBC, Fakih FT, Oliveira RC. Aspectos gerais e número de etapas do sistema de medicação de quatro hospitais brasileiros. Rev. Latino-Am. Enfermagem. 2004;12(5):781-9.

16. Piva JP, Garcia PCR. More, more and even more B2 adrenergic agents for treating acute asthma in children: is the adrenergic approach the only way?. Pediatr Crit Care Med. 2002;3(2):202-3.

17. American Society of Health-System Pharmacists (ASHP). Technical assistance bulletin on hospital drug distribution and control. Am J Hosp Pharm. 1980;37(8):1097-103.

Received: Jul. 27th 2009

Accepted: Jul. $23^{\text {rd }} 2010$ 